Kohl: a Journal for Body and Gender Research Vol. 2, No. 2 (Winter 2016)

\title{
Unlayering the Other: a Queer Armenian Experience
}

Chant 
The first time I heard the word Odar was when it was used to define my mother. Odar, an Armenian word, means strange, foreign, queer, not from within the community or circle or ethnic group. Basically, nonArmenian. The word's racist, normative implications are not considered; it is just seen as a word that defines an "us" versus a "them" - what is inside the circle and what is outside of it. Things "we" do and things others do.

The more I thought about this, the more I realised its intersection with my queerness and how it was also perceived as something outside of the Armenian community. The more I tried to understand this, the more many variables and complex conditions seemed to come into play. However, one thing was very striking as I looked back at the past century, trying to understand the Armenian community as some homogeneous entity: our bodies carried so much shame, and Armenian women have not only been absent in genocide literature, but also in post-genocide analyses. It slowly dawned on me that Armenians were nothing close to the homogenous entity they liked to believe themselves to be.

When so much of our Armenian identity gets rooted in the tragedy of genocide, it becomes an awfully restrictive burden to bear. When politics of identity define who you are by isolating one historical period of an entire nation, when this demarcation is the schism between Armenian diaspora - Western Armenians from Cilicia and the Anatolian Highlands, some of whom were given shelter in the Republic and the Armenians of the Republic - today's Armenia/Eastern Armenia, you find yourself in front of an inability to unify these experiences because they cannot essentially be so anyway. ${ }^{1}$

It is not an obvious precondition for Armenianness that pre- and post-USSR understand pre- and postOttomans, and the merger or similarities of experiences will never be loud enough for it to encompass or surpass all of our inner notions of nation-states and land or recuperation, integrations, assimilation, and whatnots. Still, our community is perceived as one. It is perceived as having similar values and political demands, when the truth is far from that. As Tamar Kevonian' ${ }^{2}$ puts it: "The reality of the far flung Armenian Diaspora is that we live in cultures different than the one we have tried to preserve throughout our journeys and often our friends, neighbours, coworkers and spouses are from the culture of our host countries." But diasporans are most of the time made to feel that they need to choose, because our societies are built in such a way: in order for one to fit in, they must crank themselves up in boxes and limit their identities as much as possible as to avoid confusion and complex explanations. The either/or dilemma of "identity" becomes a daily question.

For decades after the genocide and before Armenian feminists (inside Armenia and out) became more and more vocal, collective territory and identity, and cultural reproduction of the community were mostly associated with women - women who reached foreign countries with children, teenage boys, the elderly. Most of the men were either imprisoned, massacred, or made to join the Ottoman army. When these

\footnotetext{
${ }^{1}$ This genocide took place in the Anatolian area as well as what is historically known as Cilicia. Those in the Republic of Armenia (as defined today) were not under the Ottoman rule and so experienced this period differently. This is not to say that some Western Armenians did not flee to Eastern Armenia (the motherland). The Republic of Armenia (Eastern Armenia) later on fell under the USSR bloc, while simultaneously, survivors of the genocide started creating diasporic communities all over the world.

${ }^{2}$ http://asbarez.com/79459/racist-who-me/
} 
women and children arrived to the camps, there are rare mentions of how they survived, thrived, rebuilt. They seem to be discredited or their feats limited to the passing/teaching of culture and history to the younger generations. Rare is their manual labour seen as something other than craftsmanship or as economic agency. It is rare that we speak of these things, let alone of the women who rebuilt communities or the experiences that affected their entire lives as well as those of their children. Women and young girls were not only subjected to rape, but also forced marriage, torture, forced prostitution, being sold into slavery, as well as sexual mutilation. As Sanasarian ${ }^{3}$ puts it: "Despite a wealth of literature on the Armenian genocide, little research has been done on women who made up the mass of the deportees. The significance of gender differences in the genocidal process has been neither empirically conceptualised nor systematically analysed." Until a couple of decades ago, not many scholars researching, writing, or discussing genocide distinguished victims in terms of gender. Instead, they spoke of the victims of the genocide as an entity, as intersecting "victims of." Truth is that genocides are not gender-blind, and they are informed by the assumed/normative gender of the population. This is obvious through gender-based crimes, be it against women or men. ${ }^{4}$

Cynthia Enloe argues that "nationalism has typically sprung from masculinised memory, masculinised humiliation, and masculinised hope." 5 And so, in this "collective" memory, there is no room for women or their perceived shame. The abused women were impure, tainted, and despised, even though they were the ones who suffered most. But nations, borders, and victories are honours that trump body integrity. After all, in war, it is the first thing expected to be put on the line. In genocide, men rape in groups because they are ordered to, because it becomes a commodity, or because they are systematically permitted to do so. It is premeditated in the hierarchy. The men rape not as individual men, but as members of their race, ethnicity, religion, or nationality. When a woman is raped, assaulted, taken against her will, she no longer belongs to herself or her culture. She is considered soiled. She becomes the possession of the violator even long after the violator exits the picture. As if he has left his mark on her and branded her like cattle. She also becomes a commodity of that nation, of its military structure. Her narrative becomes bundled with that of so many other women; the trauma is historicised as a violent act on the nation and its progenitor and no longer on her self. Her tattooed face and hands 6 with symbols of the enemy or of her position within her new "race" make her a possession, her forced pregnancy a vessel of shame, the creation of tainted children, passing on the violation and denigration by the enemy and its state.

We do not take into account that the traumas of these women remain untold, untreated, and unacknowledged for fear of affecting a certain social order. We consider them holders of the family honour conditioned by shame. We render the bodies foreign, separate, distinct from the ideal self, the communal

\footnotetext{
${ }^{3}$ Sanasarian, Eliz. "Gender Distinction in the Genocidal Process: A Preliminary Study of the Armenian Case." Holocaust and Genocide Studies 4, 4 (1989): 449-461, 449.

${ }^{4}$ In the case of men, they serve in feminising enemy male bodies and rendering them subject to a patriarchal, militarised, conquering, institutional power. Far from being a homosexual act, it forcibly takes something fundamental to one's sexual identity away, by rendering them weak and feminine against their will, by making them a lesser subject.

${ }^{5}$ Enloe, Cynthia. Bananas, Beaches and Bases: Making Feminist Sense of International Politics. Berkeley: University of California Press, 1989. 44.

${ }^{6}$ The Armenian women and girls who were kidnapped by or sold to Bedouin families were islamicised and tattooed with magical symbols, religious symbols, or those of ownership.
} 
self. Often, we blame the survivor and alienate them. In their isolation, they see themselves as the ones at fault. And more often than not, we opt for silence and blindness because more important things are at stake, and how do you build the nationalist dream on broken and assaulted bodies? On foreign nonconforming bodies? It is better to be silent than to be excommunicated.

It is the same fear of becoming an outcast in such a small community that haunts "Armenian"7 queer individuals up until today. It is difficult for many Armenian families to accept non-Armenian members, or those from the LGBT community. They consider these as odars or odar-ified members who do not live up to the Armenian ideal, and are consequently alienated. What is the Armenian ideal? No one knows, really, but most are ready to tell you what is not. ${ }^{8}$ One thing they all seem to agree on is the notion of shame (amot, in Armenian), a perfected psychological currency in the community/family. Whenever something is disproved by a parent/society, it is amot, and there is a general consensus that if people do not talk about what is amot, it will go away.

Homosexuality, as many Armenians would tell you, is limited to the west. It is foreign, odar. Like my mother, a non-Armenian. Like myself a "half of each," and my sexuality, non-conforming. But borders are not fixed, and neither are notions of foreignness. The margins expand, become undone, get redrawn, just like our bodies. It is in our transgression of the shame of all of those who tell us what we are not. It is in transgressing what is amot (shameful) that we decide to be what we want to be, and not vessels and holders of the ideals of others - ideals rooted in patriarchy and the glorification of nation-states. We are bred and expected to build our country, to go back to the motherland. Which motherland is that that we speak of? Diasporas spread across hundreds of countries; they now move across literal and figurative borders, the children of today's Republic exiting year after year and relocating. Are we supposed to believe that our Armenianness is so inherent that we have all come to an agreement as to what it actually is in its essence? Soldiers and protectors of the nation? Not only do these essentialised notions rigidify identity politics, but they also disentangle the intersections of what is and is not. When exploring intersections of immigration, ethnicity, and sexuality, odar becomes a construct that keeps diasporans, migrants, the non-conforming, out. It tries to box different parts of you as mutually exclusive or oppositional, leaving you with no agency. It becomes a local or community-based construct defining what is from it and what is odar to it, what is attributed to it and what is outside of it, what is familiar and what is constructed, messing up its borders, definitions, and abstract notions of "purity."

\footnotetext{
${ }^{7} \mid$ use the word here for whoever wishes to identify as such and not as a limited circle whose identity is set in stone and immutable.

${ }^{8} \mathrm{~A}$ stroll around online forums sheds light on some of the things that are considered Armenian. The bloodline/being a "total Armenian", the church/being Christian, the soldiers and nationalism, the genocide, raising Armenian children (in the church of course) and so on.
} 